\title{
Rolling Ironstones from Earth and Mars: Terrestrial Hydrothermal Ooids as a Potential Analogue of Martian Spherules
}

\author{
Marcella Di Bella 1,2,*, Franco Pirajno ${ }^{3}$, Giuseppe Sabatino ${ }^{4}{ }^{\mathbb{D}}$, Simona Quartieri ${ }^{5,+}{ }^{\mathbb{D}}$, Roberto Barbieri ${ }^{6}$,

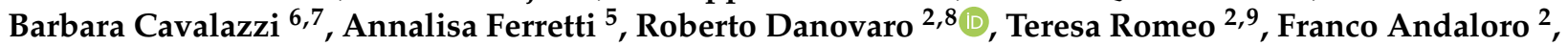 \\ Valentina Esposito ${ }^{10}$ (D) Gianfranco Scotti ${ }^{9}$, Alessandro Tripodo ${ }^{4}$ and Francesco Italiano ${ }^{1}$ (D)
}

check for updates

Citation: Di Bella, M.; Pirajno, F.; Sabatino, G.; Quartieri, S.; Barbieri, R.; Cavalazzi, B.; Ferretti, A.; Danovaro,

R.; Romeo, T.; Andaloro, F.; et al. Rolling Ironstones from Earth and Mars: Terrestrial Hydrothermal Ooids as a Potential Analogue of Martian Spherules. Minerals 2021, 11, 460. https://doi.org/10.3390/min11050460

Academic Editor: Kattathu Mathew

Received: 4 March 2021

Accepted: 24 April 2021

Published: 27 April 2021

Publisher's Note: MDPI stays neutral with regard to jurisdictional claims in published maps and institutional affiliations.

Copyright: (c) 2021 by the authors. Licensee MDPI, Basel, Switzerland This article is an open access article distributed under the terms and conditions of the Creative Commons Attribution (CC BY) license (https:/ / creativecommons.org/licenses/by/ $4.0 /)$
1 Istituto Nazionale di Geofisica e Vulcanologia (INGV), Sezione di Palermo, Sede Operativa di Milazzo, Via dei Mille 46, 98057 Milazzo, Italy; francesco.italiano@ingv.it

2 Sede Territoriale Sicilia, Dipartimento di Ecologia Marina Integrata, Stazione Zoologica Anton Dohrn (SZN), Via dei Mille 46, 98057 Milazzo, Italy; r.danovaro@staff.univpm.it (R.D.); teresa.romeo@szn.it (T.R.); franco.andaloro@szn.it (F.A.)

3 Centre for Exploration Targeting, University of Western Australia, 35 Stirling Highway, Crawley, Perth, WA 6009, Australia; franco.pirajno@uwa.edu.au

4 Dipartimento di Scienze Matematiche e Informatiche, Scienze Fisiche e Scienze della Terra (MIFT), Università di Messina, Viale Stagno d'Alcontres 31, 98166 Messina, Italy; gsabatino@unime.it (G.S.); atripodo@unime.it (A.T.)

5 Dipartimento di Scienze Chimiche e Geologiche (DSCG), Università di Modena e Reggio Emilia, Via Campi 103, 41125 Modena, Italy; simona.quartieri@unimore.it (S.Q.); ferretti@unimore.it (A.F.)

6 Dipartimento di Scienze Biologiche, Geologiche e Ambientali (BiGeA), Università di Bologna, Via Zamboni 67, 40126 Bologna, Italy; roberto.barbieri@unibo.it (R.B.); barbara.cavalazzi@unibo.it (B.C.)

7 Department of Geology, University of Johannesburg, P.O. Box 524, Auckland Park, Johannesburg 2006, South Africa

8 Dipartimento di Scienze della Vita e Ambientali (DISVA), Università Politecnica delle Marche, Piazza Roma 22, 60121 Ancona, Italy

9 Istituto Superiore per la Protezione e la Ricerca Ambientale (ISPRA), Laboratorio di Milazzo, Via dei Mille 44, 98057 Messina, Italy; gianfranco.scotti@isprambiente.it

10 Istituto Nazionale di Oceanografia e di Geofisica Sperimentale (OGS), Via Auguste Piccard 54, 34151 Trieste, Italy; vesposito@inogs.it

* Correspondence: marcella.dibella@ingv.it

+ Now retired.

Abstract: High-resolution images of Mars from National Aeronautics and Space Administration (NASA) rovers revealed mm-size loose haematite spherulitic deposits (nicknamed "blueberries") similar to terrestrial iron-ooids, for which both abiotic and biotic genetic hypotheses have been proposed. Understanding the formation mechanism of these haematite spherules can thus improve our knowledge on the possible geologic evolution and links to life development on Mars. Here, we show that shape, size, fabric and mineralogical composition of the Martian spherules share similarities with corresponding iron spherules currently forming on the Earth over an active submarine hydrothermal system located off Panarea Island (Aeolian Islands, Mediterranean Sea). Hydrothermal fluids associated with volcanic activity enable these terrestrial spheroidal grains to form and grow. The recent exceptional discovery of a still working iron-ooid source on the Earth provides indications that past hydrothermal activity on the Red Planet is a possible scenario to be considered as the cause of formation of these enigmatic iron grains.

Keywords: Blueberry; iron grains; hydrothermal system; haematite; goethite; Mars; Panarea

\section{Introduction}

NASA's rover missions have explored the surface of Mars with the aim to assess local aqueous environments, and with the specific goal of finding evidence of past or present 
life. The presence of haematite deposits detected in different areas near the equator-by Thermal Emission Spectrometer (TES) on the Mars Global Surveyor (MGS) [1] - has been used to argue for the presence of liquid water on Mars in the distant past. Within regions in which haematite was detected, the Mars Explorations rovers (MER) Opportunity and Spirit discovered mm-size haematite spherules during NASA's missions. The Martian haematite spherules (Figure 1A,B) have been reported both from in-situ soil deposits and from aeolian dunes as well [2]. Specifically, MER rovers detected in-situ spherules at Meridiani Planum (Opportunity) and on the floor of the Gusev Crater (Spirit) [2,3]. Extensive observations with the Mössbauer [4,5], Alpha-Particle X-ray Spectrometer (APXS) [6] and Mini-TES [7] instruments, confirmed that these spherules are dominantly composed of hematite. These spherules are found within and around outcrop rocks (Figure 1C) at Meridiani Planum, and rolling into the interior of Endurance crater (Figure 1D) [7].
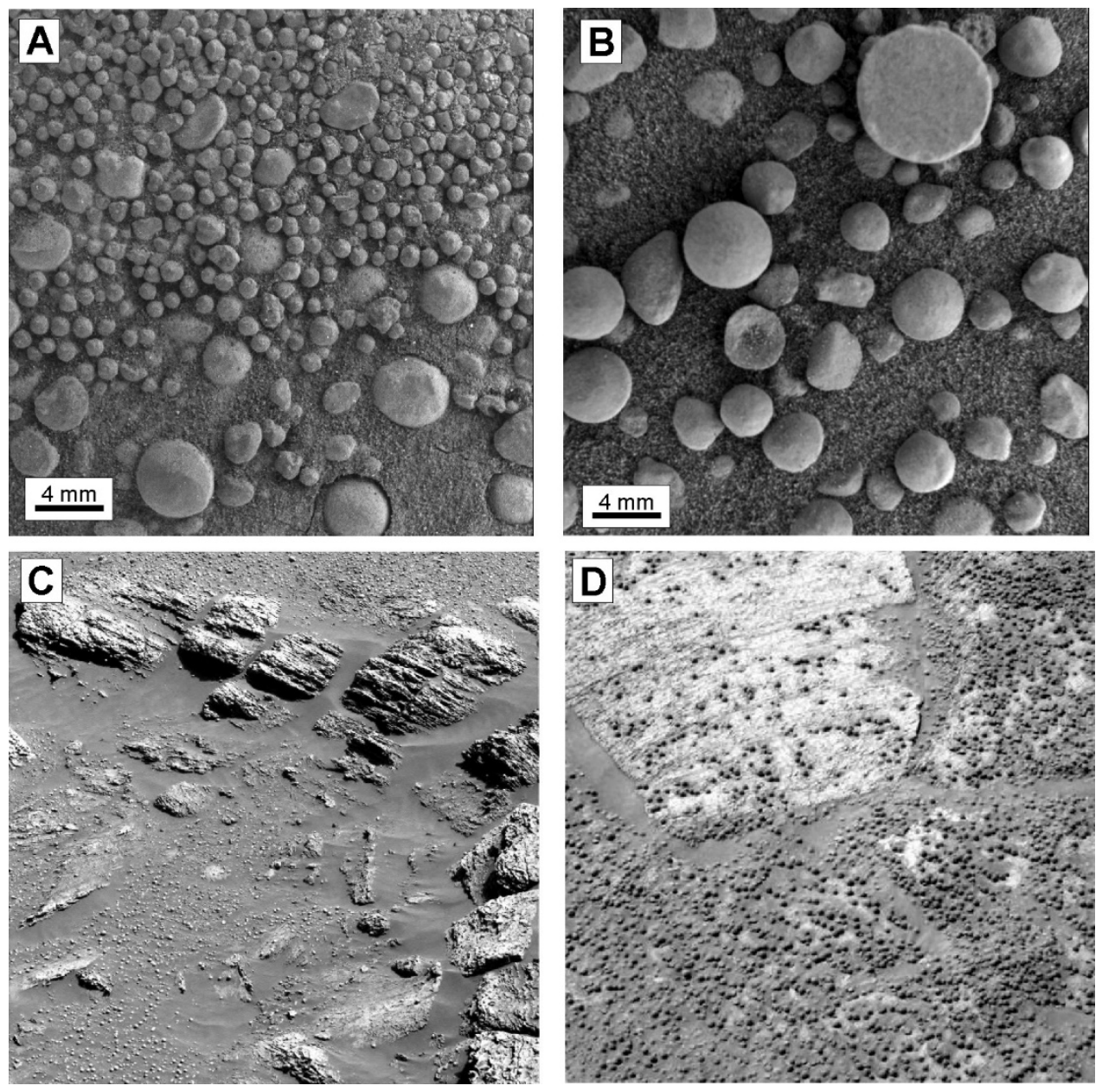

Figure 1. Martian iron spherules recovered in soil deposits and aeolian dunes from the Red Planet. $(\mathbf{A}, \mathbf{B})$ Haematite spherules in the iron-rich soil of Meridiani Planum acquired by the Microscopic Imager on NASA's Mars Opportunity rover (sol 924-1m135641102iff1300p2956m2f1_0PCT near Victoria Crater and sol 84-1m210211964iff758zp2957m2f1_OPCT beside Fram Crater, which Opportunity passed on its way from Eagle Crater, respectively). (C) Sedimentary, thickly laminated, evenly stratified rock type, containing haematite spherules, which forms stratigraphically beneath cross-bedded sandstones interpreted as ancient river deposits. This panoramic image was taken by NASA's Opportunity rover on Sol 14 Pancam images of the northeast end of the Eagle crater, at Meridiani Planum. (D) Layered sedimentary rocks containing haematite spherules which are also scattered on soils. This panoramic image was taken by NASA's Opportunity rover on Sol 109 Pancam images of the rim of Endurance Crater at the Meridiani Planum. 
A variety of hypotheses have been formulated to explain the origin of the Martian haematite spherules. However, only a few studies focused on the mechanisms by which they might have originated. One of the most accredited hypotheses was based on an analogy with the terrestrial "blueberries", which are spherules cemented by haematite after their deposition, found in the Jurassic Navajo sandstone of southern Utah [8-10]. The model suggested that the formation of Martian spherical haematite grains required the presence of a permeable host rock and groundwater flow [9]. Recently, the analogy with the Utah blueberries has also been stressed by Yoshida et al. [10], who proposed a formation in early Martian history due to the interaction between pre-existing calcite spherules and acidic sulphate water infiltrated into the soils. Other genetic mechanisms support the following hypotheses: (1) concretions from stagnant groundwaters [11-13]; (2) meteorite impact [14,15]; (3) interactions between volcanic deposits and acidic hydrothermal fluids [16,17]; (4) freezing of aqueous haematite nanoparticle suspensions [18].

As a whole, Martian deposits exhibit features similar to the ancient terrestrial haematiterich deposits known as Granular Iron Formations (GIF), in which iron concretions are found as well [19]. GIF formed in shallow marine continental shelf to coastal conditions [20] and are related to a period of mantle plumes breakout that resulted in global magmatism and supercontinent breakup [20]. The origin of granules in GIF has long been the subject of speculation and wide debate [19].

Martian spherules also match terrestrial iron-ooids, made of a nucleus surrounded by mineral iron-oxides/oxyhydroxides precipitated in the form of spheroidal laminated coatings. Here we propose a new model of formation for Martian haematite-spherules, based on striking mineralogical and morphological similarities with modern iron-ooids forming in a submarine hydrothermal vent area close to the volcanic island of Panarea, in the Aeolian Arc (Mediterranean Sea) [21]. We investigate the implications for similar hydrothermal-related formation mechanisms, also referring to the geochemical features of the sedimentary rocks in which they are embedded. This model can be applied to commonly observed Fe-oxide laminated grains at other sites that formed in similar sedimentary facies and a volcanic environment. On the basis of this evidence, we propose evaluating the terrestrial iron ooids from Panarea and terrestrial-GIF granules as potential analogues of the Martian haematite spherules.

\section{Features of the Martian Haematite Spherules and Related Sedimentary Rocks in Meridiani Planum}

The TES on the MGS orbiter discovered on Mars a large area covered by haematite at Meridiani Planum, as well as in other equatorial regions [22]. Afterwards, the analytical instruments on board the Opportunity rover confirmed the presence of haematite in the form of concretions/spherules (Figure 1A,B), which were called "blueberries" by the mission scientists. These grains were discovered embedded in S-rich sedimentary layered bedrocks (Figure 1C,D) and on the surface of dune crests as whole and broken spherules [7]. Spherule size and shape do not change significantly along the more than $7 \mathrm{~km}$ traversed by Opportunity from Eagle Crater to Victoria Crater. Martian spherulitic grains generally range from sub-mm to several $\mathrm{mm}$ in diameter (from less than 1 to $6.7 \mathrm{~mm}$ ) and are mostly spheroidal or elongated (Figures 1A,B and 2A), with more complicated shapes resulting from spherule coalescence during growth $[7,13]$. Some angular grains, interpreted as spherule fragments, were observed on top of ripple crests in association with smaller rounded grains [7,23]. In outcrop exposures abraded by Rock Abrasion Tool (RAT) [7], cross sections of spherules observed with Microscopic Imager (MI) show them to be homogeneous and apparently lacking internal structures (i.e., nucleus and cortical laminae). However, the presence of dark cored spherules [14], which may represent the evidence of an internal nucleus, is perceptible for instance in Sol 1217 image from NASA (Figure 2A). Further information on the internal structure of iron spherules at Meridiani Planum are provided by TES-MGS, and mini-TES instrument (on-board the Opportunity rover) $[24,25]$. The absence of $390 \mathrm{~cm}^{-1}$ band in the thermal infrared spectrum of haematite has been in fact related to an internal laminated fabric of the spherules, composed of 
platy crystals concentrically grown [26] (Figure 2B). Moreover, some NASA images-for instance, Sol 1166 (not shown)—suggest the probable presence of a laminated iron-oxide outer cortex.
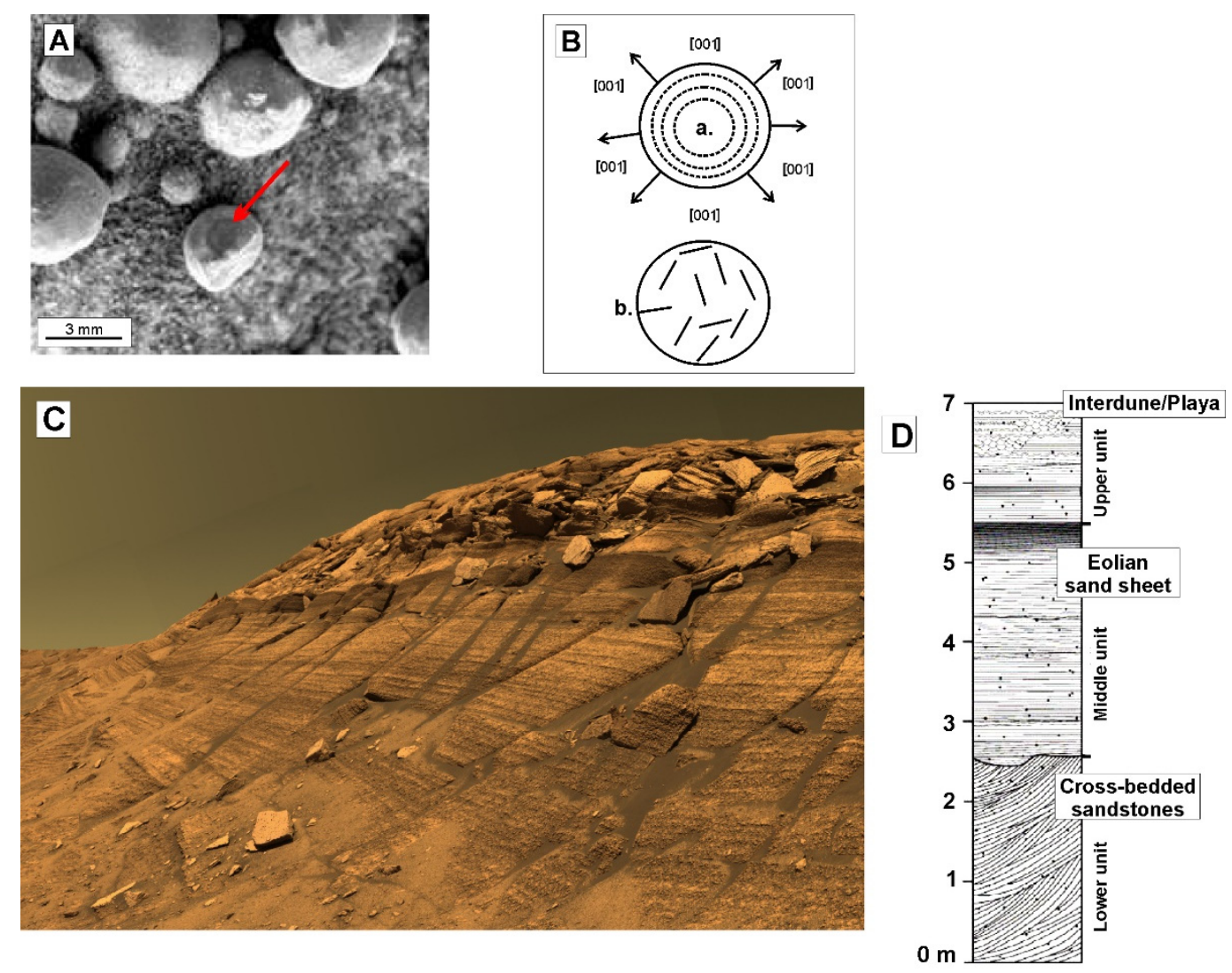

Figure 2. Internal structure of Martian spherules and overview of the Burns Formation exposed at Meridiani Planum. (A) Presence of a possible nucleus in a spherules (see red arrow), image acquired by the Microscopic Imager on NASA's Mars Opportunity rover; spherule is about $3 \mathrm{~mm}$ in diameter (Sol 1216). (B) Internal fabric of a modeled haematite-spherule (a) revealing concentrically grown anhedral haematite crystals with a lattice preferred orientation dominated by [1] axis emission and a modeled spherule (b) composed of concentrically grown anhedral haematite crystals (after Glotch et al., 2006) [26]. (C) Exposure of the Burns Formation at Burns cliff on the southeast rim of Endurance crater; image by the Panoramic Camera on NASA's Mars Opportunity rover. (D) Stratigraphy of the Burns Formation, modified from Grotzinger et al. [12].

Concerning Meridiani Planum bedrocks, the Panoramic Camera (Pancam) on the Opportunity rover, showed that they are flat-lying sedimentary rocks, finely laminated (mm scale) and cross-stratified, composed of haematite spherules mixed with sulphates, clays and basaltic sand. The entire sequence of "Burns Formation", was examined by Opportunity in the Endurance crater [12] (Figure 2C). The 30-40 cm (at Eagle crater) to $7 \mathrm{~m}$ (at Endurance crater) exposed succession has been sub-divided in Lower, Middle and Upper units, which were respectively interpreted as aeolian dune fields, aeolian sand sheets and interdunes/playas [12] (Figure 2D). Explicitly, the succession consists of a sulphate-rich bottom unit, an intermediate clay-enriched unit, and a top most sulphate-rich unit [27,28]. The layered bedrocks have been interpreted as emplaced by aeolian and aqueous processes, probably formed at Meridiani from a local source area rather than transported from a distant source [11,12]. 


\section{Materials and Methods}

\subsection{Study Approach, Sample Collection and Processing}

We analyzed data and images of Martian spherules and related soils provided by NASA rovers (e.g., [5,29-31]) and then we compared them with the terrestrial iron ooids from Panarea Island, Italy. The data we took into account include: (a) mineralogy and fabric of the spherules, as well as texture and structure of the sedimentary terrains captured by Opportunity rover at Meridiani Planum using Microscopic Imager (MI) and Panoramic Camera (Pancam); (b) mineralogy of iron-bearing rocks and soils containing spherules acquired by Spirit and Opportunity rovers using Mini-Thermal Emission Spectrometer (Mini-TES) and Mössbauer (MB) spectrometer; (c) abundance of the elements that make up rocks and soils-containing spherules performed by the Alpha Particles X-ray Spectrometer (APXS) fit on the Spirit and Opportunity rovers.

The terrestrial ooids from Panarea, studied in detail Di Bella et al. [21], come from a sand sampled off the east coast of Panarea Island (Figure 3A) during a research cruise carried out by the Italian Institute for Environmental Protection and Research (ISPRA) and the National Institute of Geophysics and Volcanology (INGV) on board the research vessel Astrea. The sample was collected at a depth of $80 \mathrm{~m}\left(38^{\circ} 40.429 ; 15^{\circ} 07.651 \mathrm{E}\right)$ over an area located NE of Basiluzzo islet, where the venting of hydrothermal fluids is spread along the slope of the escarpment towards the island of Stromboli from 80 to $400 \mathrm{~m}$ b.s.l. and controlled by NE-SW and NW-SE fault systems. Further images and compositional data acquired on this material [18] provided a better insight into their fabric, morphologies, mineralogy and composition. The collected sample is composed of a whitish biogenic component and dark rust-colored grains (mostly ooids) (Figure 3B). Ooids were separated from the biogenic material by hand-picking under a Zeiss Stemi SV 11 binocular microscope and analyzed and photographed using optical and electron microscopy. Some ooids were set in epoxide resin (araldite) in small plastic containers and, when dry, used to produce artificial uncovered polished thin-sections ( $30 \mathrm{~mm} \times 45 \mathrm{~mm}$ and $30 \mu \mathrm{m}$ thick) and polished slabs $(20 \mathrm{~mm} \times 20 \mathrm{~mm}$ ) (at the CIGS laboratory of the Modena and Reggio Emilia University, Italy). The polished thin sections were first examined by a transmitted optical light microscope (Zeiss Axioscope microscope at the laboratory of the Messina University, Italy and Olympus BX51 at the Centre de Biophysique Moléculaire, CNRS, France, in Orléans, France), and then analyzed by environmental scanning electron microscopy (ESEM). A powdered sample was also analyzed by means of synchrotron X-ray powder diffraction, in order to define the mineralogical composition of cortex and nuclei.

\subsection{Synchrotron X-ray Powder Diffraction (XRPD)}

The synchrotron XRPD patterns were collected at ID22 beamline at European Synchrotron Radiation Facility (ESRF) of Grenoble (France) with a fixed wavelength of $0.354183 \AA$ (calibrated with Si NIST standard reference material). The wavelength was calibrated with Si NIST standard reference material. The sample was ground with an agate mortar to a crystallite dimension of $9-10 \mu \mathrm{m}$ and then loaded and packed into a $0.7 \mu \mathrm{m}$ silica glass capillary. The capillary was mounted on a standard goniometric head and kept spinning during pattern collection. Diffraction patterns were recorded with a high-resolution multi-analyzer stage composed of nine analyzer crystals in the $2 \theta$ range $0-42^{\circ}$. X-ray diffraction images were integrated with Fit2d software. Selected powder diffraction patterns are reported in Figure 4 . 

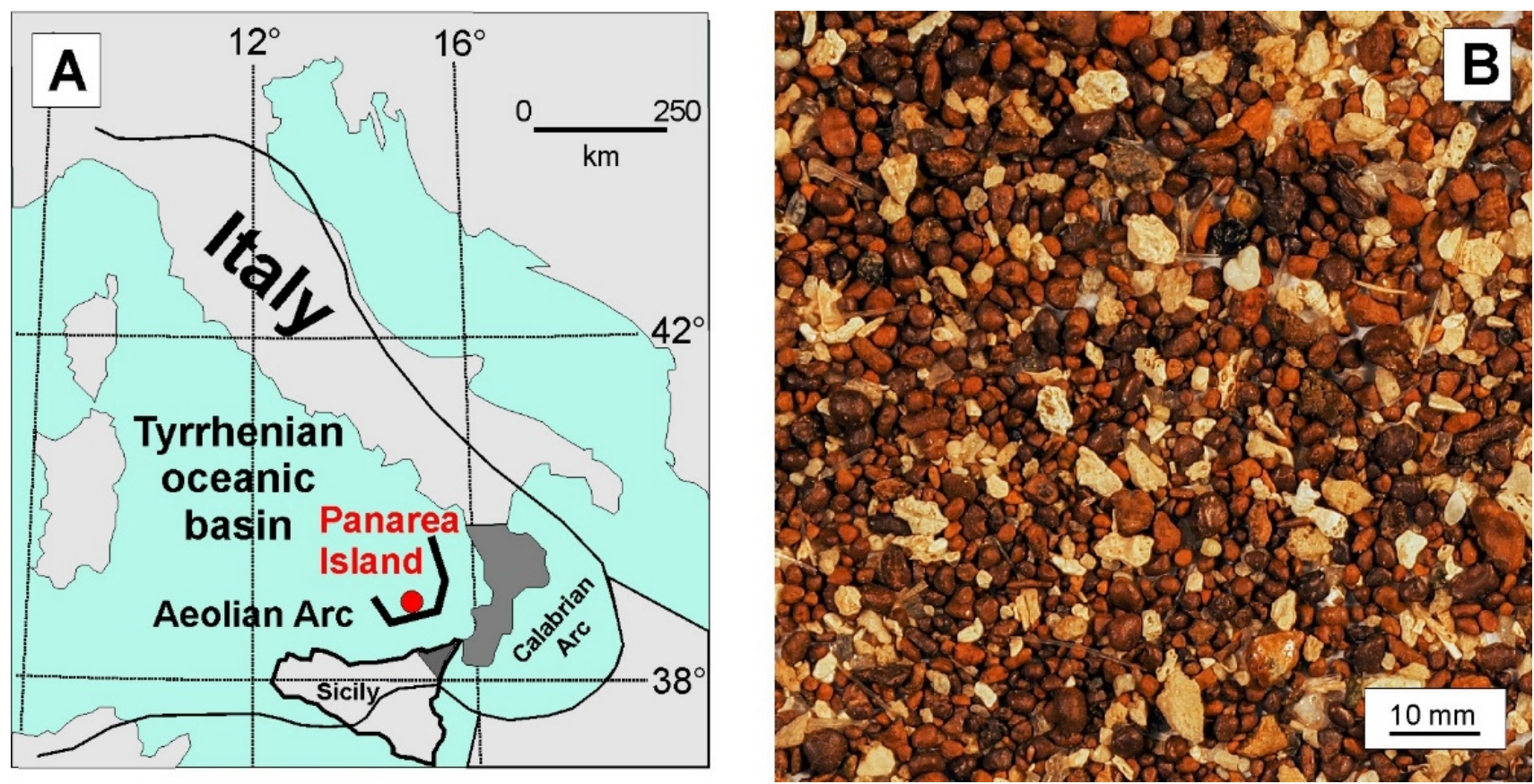

Figure 3. (A) Location map showing the Aeolian volcanic arc and Panarea Island (red spot). (B) Stereomicroscopy photograph of Panarea ooidal sand (dark red-brown grains) in which a whitish biogenic material is clearly recognizable.

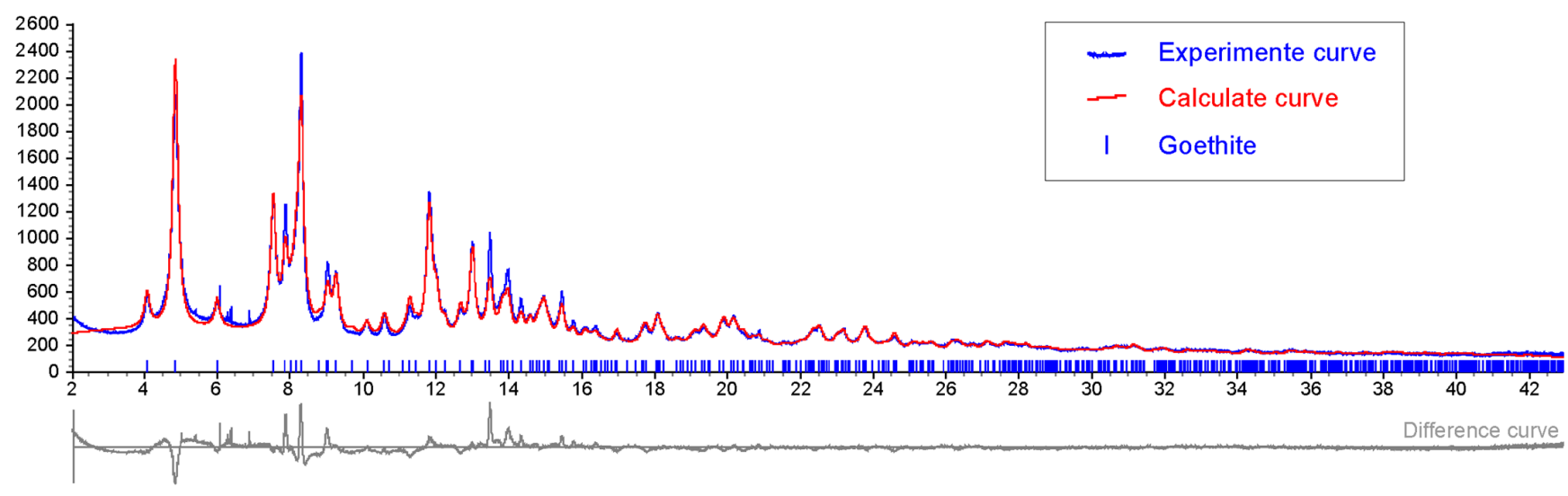

Figure 4. Synchrotron X-ray powder diffractometric pattern of Panarea ooids. The unique Fe-rich mineral identified is goethite.

\subsection{Scanning Electron Microscopy}

Visual investigations on polished sections were carried out on an ESEM-FEI Inspect-S instrument equipped with an Oxford INCA PentaFETx3 EDS and a Si(Li) detector having an ultra-thin window ATW2 (MIFT Department of Messina University), with a resolution of $137 \mathrm{eV}$ at $5.9 \mathrm{keV}$. Data acquisition was performed under environmental conditions, working at a distance of $10 \mathrm{~mm}$ with an acceleration voltage of $20 \mathrm{kV}$ and a counting time of $60 \mathrm{~s}$, approximately $3000 \mathrm{cps}$ with dead time below $30 \%$. The obtained semi-quantitative data were processed by the INCA software Energy. This software uses the exponential matrix correction scheme (XPP) developed by Pouchou and Pichoir [32,33].

\section{Geological Context and Hydrothermal Activity at Panarea Island}

Panarea Island belongs to the Aeolian volcanic arc, which is related to the subduction of the Ionian Sea floor beneath the Southern Tyrrhenian Sea (see Figure 3A). The volcanic arc comprises seven islands (Alicudi, Filicudi, Salina, Vulcano, Lipari, Panarea and Stromboli) and several volcanic seamounts (Sisifo, Enarete, Eolo, Alcione and Palinuro) arranged in a 
largely submarine, ring-shaped complex of volcanic edifices around the Marsili basin and seamount $[34,35]$.

The Panarea Volcanic Complex represents the emergent part of a submarine composite volcano, largely dismantled by erosion and volcano-tectonic collapses $[36,37]$. The eruptive history of this wide volcanic system is divided into six successive eruptive epochs with periods of volcanic activity separated by quiescence stages, the last of which contributed to the emplacement of the Basiluzzo endogenous dome (54 $\pm 8 \mathrm{ka})$. To the east of Panarea, the islets of Basiluzzo, Dattilo, Panarelli, Lisca Bianca, Bottaro, Lisca Nera and Formiche form a small archipelago that emerges from the eroded submarine shelf at the top of the volcano. Panarea and Basiluzzo islets are surrounded by an abrasion platform, similar in size to that of the other Aeolian Islands. The most remarkable active tectonic structure of the area is a NNE-SSW, NE-SW trending graben, located North-East of Panarea. The western boundary of the graben, consisting of a NNE-SSW, NE-SW trending extensional fault array, coincides with a series of escarpments, along which fresh volcanic rocks outcrop. Gas venting is frequent at the base and at the top of these faults. In the sedimented areas close to the faults, hydrothermal activity revealed by the presence of gas venting, white patches, bacterial mats and Fe-oxyhydroxides precipitates relative to past and recent hydrothermal centered activity [37,38]. Moreover, massive $\mathrm{Ba}-\mathrm{Pb}-\mathrm{Zn}$ enriched sulfide accumulations were reported to the south of the islet of Basiluzzo along and near the eastern fault [37]. $\mathrm{Fe}^{3+}$ oxyhydroxides are widely diffused throughout the entire Panarea area, where they form chimneys, mounds and near horizontal thin deposits on sediments. Recently, lowtemperature diffuse venting has been observed during Remotely Operated Vehicle (ROV) seafloor explorations as direct evidence that the yellow to red deposits of the Panarea field are hydrothermal precipitates $[39,40]$.

The diffuse discharge at Panarea consists of streams of gas bubbles, which are mainly composed of $\mathrm{CO}_{2}(92-98 \%)$, with minor amounts of $\mathrm{N}_{2}\left(0.2-3 \mathrm{vol}\right.$. \%), $\mathrm{O}_{2}(<0.01$ vol. \%), $\mathrm{CH}_{4}$ 6-5300 vol. ppm and high ${ }^{3} \mathrm{He} /{ }^{4} \mathrm{He}\left(6 \times 10^{-6}\right)[40,41]$. Thermal water analyses reveal $\mathrm{pH}$ values of 3-7.45 and temperatures in the range of $25-30{ }^{\circ} \mathrm{C}$. The analyzed water shows a general increase in the concentration of $\mathrm{K}^{+}\left(6-26\right.$ meq. per litre), $\mathrm{Ca}^{2+}$ (10-83 meq. per litre), $\mathrm{Li}^{+}\left(0.02-0.2\right.$ meq. per litre) and $\mathrm{Cl}^{-}$(403-616 meq. per litre) and a depletion in $\mathrm{Mg}^{2+}$ (38-108 meq. per litre) and $\mathrm{SO}_{4}{ }^{2-}$ (20-57 meq. per litre) with respect to marine water $[41,42]$.

\section{Results and Discussion}

\subsection{General Features of the Panarea Ooids}

Iron-ooids from Panarea were generated in a shallow-water (80 $\mathrm{m}$ deep) volcanic/ hydrothermal environment at the seafloor sediment/water interface, with low $\mathrm{pH}$ $(\mathrm{pH} \approx 3)$, and low temperature $\mathrm{CO}_{2}$-rich hydrothermal fluids carriers of $\mathrm{Fe}^{2+}$ ions [21]. The general morphological and compositional features of the Panarea ooids (Figure 5) are: (1) spheroidal shape, variable from sub-spherical to elliptical (Figure 5A); (2) diameter size ranging from 0.2 to $0.5 \mathrm{~mm}$ (Figure 5A); (3) frequent presence of agglomerates of two-three ooids coated by iron-rich laminae; (4) presence of an internal nucleus made of volcanic and/or biogenic particles (Figure 5). Volcanic nuclei include crystals of mainly pyroxenes and feldspars, besides abundant fragments of volcanic glass such as obsidian and pumices, all representing pyroclastic sediments deposited on the seafloor; biogenic particles are mostly sponge spicules and other undetermined bioclasts; (5) common presence of coreless ooids, due as suggested by Di Bella et al. [21], to dissolution of the internal nuclei acted by the volcanic $\mathrm{CO}_{2}$-rich hydrothermal fluids continuously discharged from the seafloor; (6) a ferrous cortex, from orange to light brown in color, with a rusty appearance, composed of up to $10 \mu \mathrm{m}$ thick laminae of iron oxyhydroxide (Figure $5 \mathrm{~B}, \mathrm{C}$ ). 


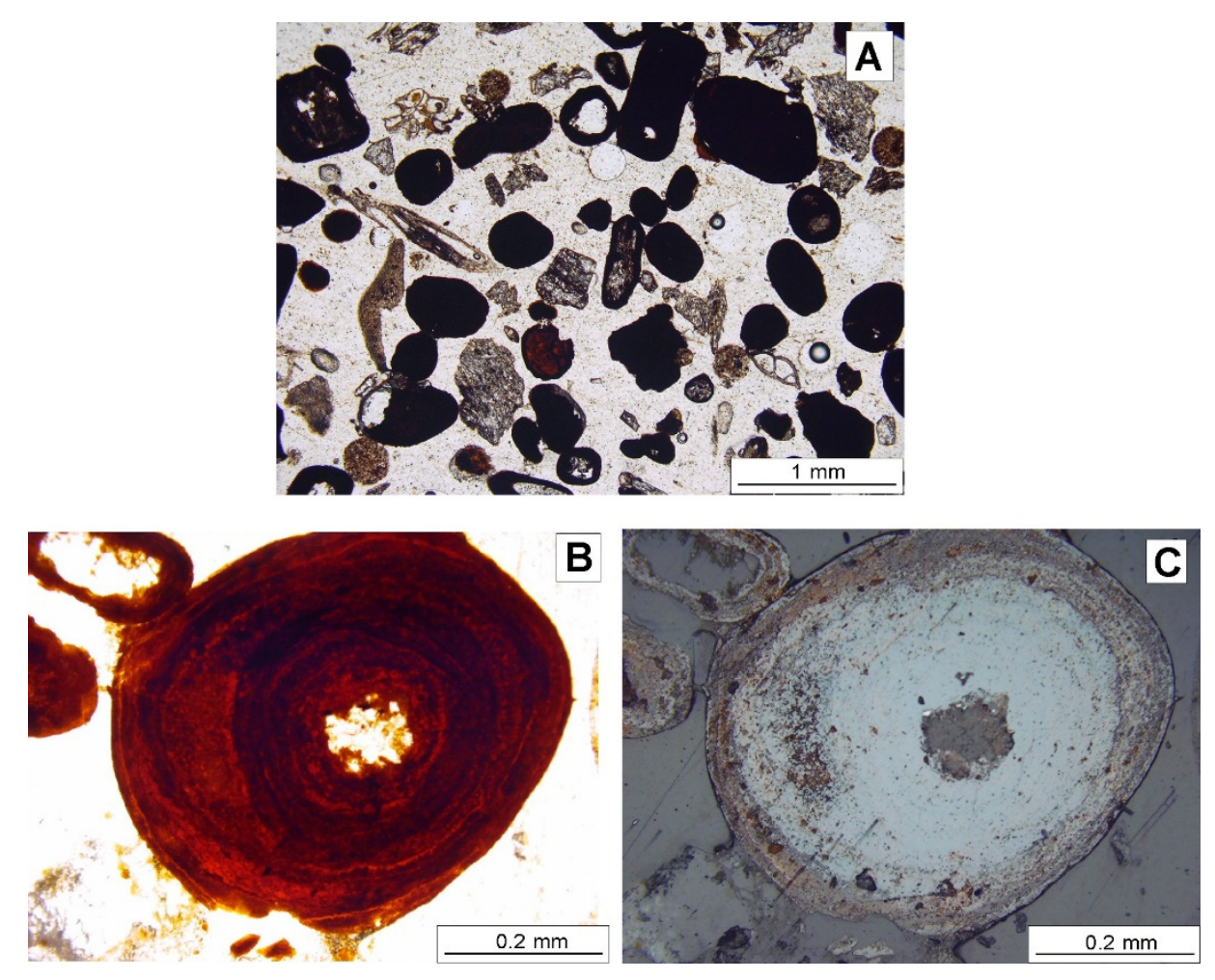

Figure 5. Terrestrial iron spherules from Panarea (Aeolian Archipelago, Mediterranean Sea). The newly formed ooids are associated to a hydrothermal origin. (A) Transmitted-light photomicrograph of thin-sectioned material illustrating main ooidal morphologies. (B) Transmitted- and (C) reflectedlight photomicrographs of a thin-sectioned ooid with goethite lamination around an indistinct nucleus. Photos B and C courtesy of F. Messori.

The presence of goethite as the main iron-oxyhydroxide phase was previously detected by conventional X-ray diffraction [21], and here confirmed using synchrotron X-ray powder diffraction (SXRPD). As shown in Figure 4 low crystalline goethite $\mathrm{FeO}(\mathrm{OH})$ is the main iron-hydroxide mineral component. The lack of other iron-bearing minerals, such as hematite, and the exclusive presence of goethite suggest that no secondary (i.e., diagenetic) processes have occurred. The rounded shape of the ooids and their composition are strictly dependent on the aqueous environment and on the continuous venting of $\mathrm{CO}_{2}$-rich hydrothermal waters [21].

\subsection{Comparing Panarea Island Ooids and Martian Haematite Spherules}

The most striking analogies between Panarea iron-ooids and Martian spherules are size, shape, fabric (Figure 6) and mineralogical composition.

Spherical and sub-spherical shapes are documented both from Panarea and Mars. Sizes are comparable as well, with the latter being slightly larger (Figure 6). The analyses of the spherule images from Meridiani Planum, taking into consideration the resolution limits of the Microscope Imager, initially suggested a bimodal distribution of the spherule size [7]. Specifically, images acquired during the traverse from Eagle to Endurance craters revealed the presence of a group characterized by diameters around several millimeters and another group with diameters of $1 \mathrm{~mm}$ or less. Observations from Endurance to Victoria Craters suggested a gradation in sizes, ranging from a few hundred micrometers to several centimeters [7]. In general, all the investigated spherules from Meridian Planum [7] showed a distribution range from less than $1 \mathrm{~mm}$ to $6.7 \mathrm{~mm}$ (Figure 6B), with the smaller population ranging from 0.68 to $1.12 \mathrm{~mm}$ in diameter. Grain size observed for the Martian spherules fits well with that of iron ooids from Panarea, with mean diameter ranging from 
0.2 to $0.5 \mathrm{~mm}$, with only a few grains reaching about $8 \mathrm{~mm}$ depending on the dimensions of the particles/nuclei on which iron coatings are nucleated [21].
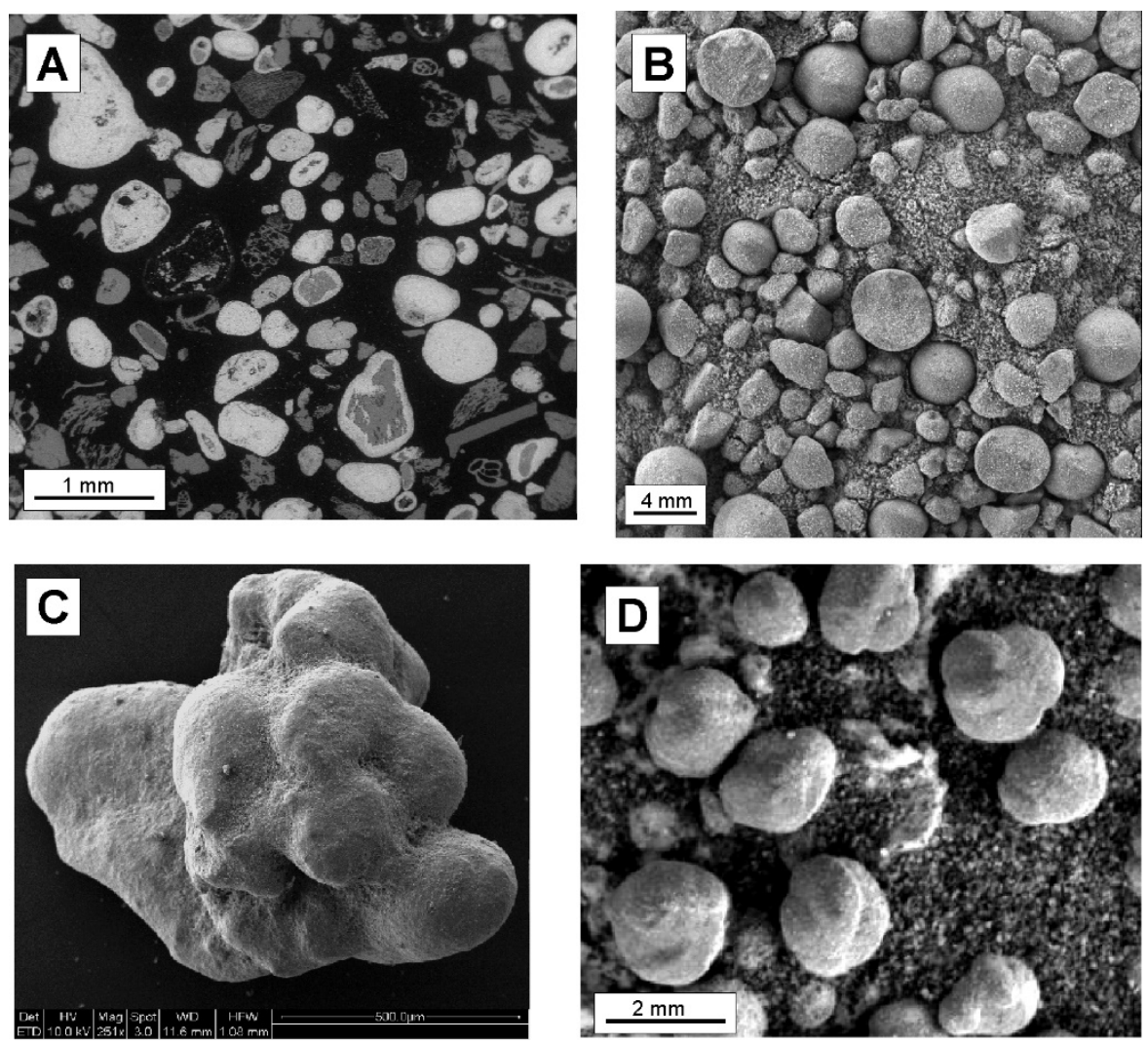

Figure 6. Similarity in shape, size and architecture between terrestrial iron spherules (Panarea ooids; left frames) and Martian iron spherules (right frames). (A) SEM-EDX image of Panarea iron ooids in polished section; (B) Martian haematite spherules in iron-rich soil, image 1m137060966iff2002p2956m2f1_0PCT acquired by the Microscopic Imager (MI) on NASA's Mars Opportunity rover. (C) SEM-BSE image of an ooidal agglomerate from Panarea, composed of associated ooids. (D) Irregular and fused grains in sol 1166, outside Victoria Crater, image 1m231695945iff820tp2936m2f1_2PCT acquired by MI on NASA's Mars Opportunity rover. Similar forms are also seen on sol 1103 and 1168.

In addition, both terrestrial and Martian iron grains mainly occur as single spheres, occasionally doubled or fused with smooth surfaces (Figure 6D) exactly like Panarea ooids (Figure 6C). Some Martian spherules, imaged prior to Opportunity's arrival at Victoria Crater, revealed odd-shaped or fused spherules such as doublets, and one triplet was also found $[7,13,23]$. In the latter part of the mission, additional unusual shapes were observed as irregular edges on spherules (e.g., sol 727, at Erebus), a "berry eating a berry" and a "duck-bill" structure (e.g., sol 924, near Victoria). Irregular shaped morphologies were observed as more common near Victoria, occurring in the background of MI images of cobble or rock targets (e.g., in sols 1103, 1166 and 1168) [7]. Irregular forms, oblate with more conical upper surfaces, are imaged in sol 929. As Panarea ooids, these bodies are characterized by both elliptical and spherical shapes, with grains showing irregular shapes, in some cases formed by agglomerates of two-three ooids. In the light of these analogies, as for the Panarea ooids, we can hypothesize that their external shape and size is dependent on the morphological features of particles on which the iron-rich coatings nucleated.

Regarding the mineralogical composition of the iron-cortex, Panarea ooids are composed of low crystalline goethite developed around nuclei of dominant abiogenic volcanic and minor biogenic origin (Figure 6A). Martian spherules are composed of haematite, although poorly crystalline goethite was also detected in Meridiani soils by Opportunity's Miniature Thermal Emission Spectrometer (Mini-TES) and Mossbauer spectrome- 
ter. Haematite was firstly detected in Meridiani Planum by TES instrument aboard the Mars Global Surveyor (MGS) spacecraft [1,22] for orbital observations. Later, Opportunity's Mini-TES spectrometer-during its observations of surfaces and soils in Meridiani Planum-showed that they had a discernable coarse-grained haematite spectral signature [43]. Further confirmation came also from Mossbauer spectrometer measurements, which identified the presence of haematite together with jarosite, and nano ferric oxide phases [43].

About the cortex lamination and the internal nucleus in Martian spherules, as well as for the Panarea ooids, their presence is quite plausible as suggested by some images by NASA (e.g., Figure 6B-F). Panarea ooids exhibit a laminated cortex of goethite (Figure 5B,C) that, according to the formation model proposed by Di Bella et al. [21], is due to the chemical precipitation of goethite laminae in dynamic conditions led by seawater/hydrothermal fluids acting as a driving force. Even if lamination in the outer cortex of Martian spherules cannot be ascertained from the images provided by the MI of the Opportunity rover, a laminated cortex of haematite is suggested also for Meridiani iron grains [26]. In this regard, Glotch et al. [26] in a study on Martian spherules, modeled the internal structure considering the absence of $390 \mathrm{~cm}^{-1}$ absorption band in the IR spectrum, as due to the presence of crystals that have concentrically grown with a laminated structure.

\subsection{Genetic Model for Martian Haematite-Spherules}

Despite the obvious differences in primordial Martian ocean-atmosphere composition and the current time geological setting of Panarea, the formation mechanism of Panarea iron-rich sediments apparently coincides with that believed to have formed proximal to active seafloor volcanic centres on Mars. Up till now, the Martian spherules genesis was considered as post-depositional or syn-depositional through groundwater filtration in porous sediments and in response to seasonal temperature, oxygen, or sediment influx changes [7]. The noteworthy presence of jarosite in the sulfate component of sediments, at Meridiani Planum, supports the hypothesis of a hydrothermal scenario. This mineral, on the Earth, originated in acidic environments characterized by low $\mathrm{pH}$ values of about 2-3 and reducing conditions. The lack of reducing conditions at Meridiani Planum [44,45], in our opinion can be interpreted as evidence of hydrothermal conditions making less probable a groundwater filtration-never manifested by Eh and $\mathrm{pH}$ values as low as for the hydrothermal fluids - as mechanism for the spherules formations.

We suggest that Martian spherules originated in volcanic conditions when at Meridiani Planum liquid water and hot springs were present, before the sedimentary processes occurred, and hence they are pre-depositional. The putative contacts of paleo-shorelines related to the oldest Martian oceans $[46,47]$ were identified by the interpretation of data from the Mars Orbital Laser Altimeter [48-51] (Figure 7A). The geological region of Arabia Terra within which Meridiani Planum is located is set between the two identified paleoshorelines that are related to a more ancient and younger oceans [49-51]. In this region, according to Michalski and Bleacher [52], the presence of ancient supervolcanoes that produced a vast amount of lava and pyroclastic materials throughout Arabia Terra and beyond have been hypothesized. The authors call these structures "plains style caldera complexes" (e.g., Eden Patera) and though they are characterized by the presence of collapse features, low topographic relief associated with plain-style lavas and friable, layered deposits. One hypothesis proposed by Michalski and Bleacher [52] to explain the association of large calderas and explosive volcanism occur at Arabia Terra is the subduction of volatile-rich crust beneath Arabia Terra during an older event of plate tectonics. According to this possibility, these authors also suggested that during the Late Noachian to the Early Hesperian a rapid rises of magma occurred in the Arabia Terra Region due to the combination of regional extension and thermal erosion. The lower gravity and atmospheric pressure on Mars favored nucleation and ascent of magma bubbles at greater depths accompanied by greater gas expansion to which the observed ridged terranes and faulted blocks can be related. This hypothetical scenario, although on a smaller scale, well 
fits with that of the Panarea volcano. As a matter of fact, Panarea is also a collapsed volcanic caldera consisting of a graben structure characterized by NNE-SSW, NE-SW trending extensional fault array, along which hydrothermal activity occurred. Here, the hydrothermal circulation originated higher temperature Kuroko-type black ore deposits and lower temperature polymetallic sulfide deposits [38] with associated crusts of Feoxyhydroxides $[37,38]$.
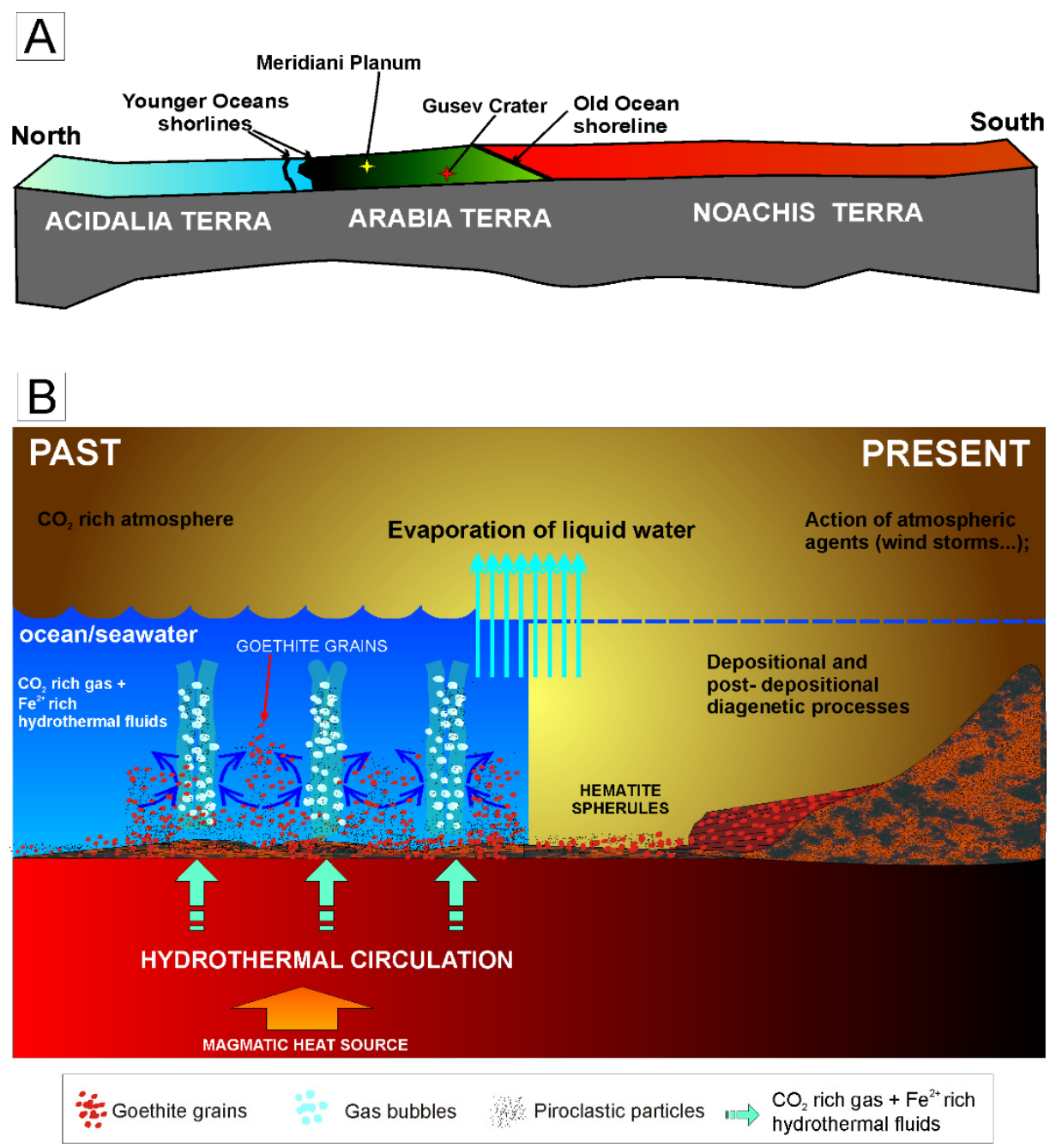

Figure 7. (A) Redrawn image from Mars Orbital Laser Altimeter (MOLA) by Dohm et al. [51], extending from the North Pole to the South Pole and including Terra Arabia Region where Meridiani Planum is located. The image displays the putative shorelines of more ancient and younger oceans between which Meridiani Planum and Gusev Crater are enclosed, suggesting that, in the past, they were areas flooded with water [48-51]. (B) Conceptual model displaying the Martian goethite spherules formation process in the past and present occurrence in soils and layered sedimentary rocks at Meridiani Planum. In the past, spherules formed in hydrothermal and acidic environment, like in Panarea area, where $\mathrm{CO}_{2}$ and Fe-rich thermal fluids triggered goethite precipitation around particles deposited on the seafloor, acting as accretion nuclei. Then, dehydration processes contributed to transform the goethite spherules into haematite spherules, which presently occur at Meridiani Planum in sedimentary deposits and within layered rocks.

Taking into account this hypothesis, we propose a scenario occurring during the late stage of volcanic activity, in which low temperature hydrothermal fluids (waters and $\mathrm{CO}_{2}$ gas emissions) seeping through seafloor sediments mixed with Martian seawater close to the sea water-sediment interface, which could have favored the rapid increase in iron and 
thus its precipitation (Figure 7B). As for the Panarea iron-ooids, we argue that the iron necessary for triggering precipitation comes from the migration of $\mathrm{Fe}^{2+}$ ions contained in pore fluids that rise from the deeper, reducing environment, to the water-sediment interface, where they precipitate as goethite at the boundary of the iron reduction/oxidation zone, characterized by low $\mathrm{pH}$ values. Here, precipitation of goethite/oxyhydroxide in laminae, whose presence is yet to be verified, occurs around nuclei made of possibly volcanic particles deposited on the Martian seafloor (Figure 7B). In order to ensure the laminated structure and the rounded shape of the spherules, sufficient energy and dynamic conditions are necessary, since they cannot acquire this peculiar laminated and rounded structure under static conditions [21].

What happened after the formation of iron-spherules? The widespread presence of isolated deposits of crystalline haematite- the anhydrous phase derived by the dehydration of goethite [25,27] — has been evidenced on the Martian surface at Meridiani Planum, Aram Chaos, Candor Chasma, and Ophir Chasma using data returned from the TES instrument aboard the MGS spacecraft [1,22]. Christensen et al. [22] listed several hypotheses on the formation of crystalline haematite on Mars: (1) low-temperature precipitation of Fe oxides/hydroxides from standing, oxygenated, Fe-rich water, followed by successive alteration to haematite; (2) low-temperature leaching of iron-bearing silicates and other materials leaving a Fe-rich residue then altered to haematite; (3) direct precipitation of haematite from Fe-rich circulating fluids of hydrothermal or other origin; (4) formation of haematite surface coatings during weathering; and (5) thermal oxidation of magnetiterich lavas. Afterwards, other studies proposed the formation mechanism of Martian haematite as derived by: (1) oxidation of magnetite-rich ash [53]; (2) low temperature $\left(300^{\circ} \mathrm{C}\right)$ transformation of primary goethite were generated by precipitation from aqueous solutions [26]; (3) direct deposition of primary haematite [54]. Our observations support the hypothesis that the Martian spherules were generated by precipitation of goethite from aqueous solutions and later transformed into haematite by temperature-induced dehydroxylation $[26,55]$ due to the changed environmental conditions. This is supported also by Lane et al. [25], who suggested a model based on the results from MGS-TES observations, where the platy haematite formed during primary deposition under stress (or burial metamorphism) of an ancient iron oxide deposit. According to these authors, the original mineralogical composition of the ancient iron oxide deposit could have consisted of a variety of ferric oxides/oxyhydroxides that were then transformed (metamorphosed) to platy haematite by aqueous or hydrothermal fluids, burial or metamorphism, followed by exhumation in recent times [25]. Calvin et al. [7] comparing laboratory and MGSTES haematite spectra found implications for haematite formation pathways on Mars. Their experiments demonstrated that the thermal emission spectra of natural (SWAN1) and synthetic haematites derived from goethite precursors by thermal dehydroxylation at $\mathrm{T} \leq 300{ }^{\circ} \mathrm{C}$ are the best match to corresponding Martian haematite spectra. Synthetic sample GTSH2-300 (goethite GTS2 precursor dehydroxylated at $300^{\circ} \mathrm{C}$ in a pseudomorphic and topotactic transformation) provides the best overall fit.

Overall, our data, combined with evidence of both past and more recent presence of water on Mars (e.g., [56]), are in good agreement with a hydrothermal vent origin for the Martian iron spherules [57].

\subsection{Evidence of Past Hydrothermal Activity on Mars}

The geological and hydrothermal processes presently active in the volcanic area of Panarea allow for reconstructing the possible conditions that can be traced to past hydrothermal activity and volcanism on the Red Planet.

Hydrothermal systems have been hypothesized to have been (or still are) active around and within Martian volcanic edifices, along the major fracture and dyke systems, and overall in the great Valles Marineris rift system [57], where layered deposits associated with water-altered minerals [58-63] have been recognized by OMEGA and CRISM imaging spectrometers $[64,65]$. In any case, the presence of volcanoes, sedimentary successions 
and rifts in several regions located along the equatorial region of Mars indicates that the Red Planet was geologically active in the relatively recent past. Moreover, the presence of valley networks suggests that in the early time Mars was wet and warmer than present-day, hence it is reasonable to assume that hydrothermal systems may have been active [20]. Indications of past hydrothermal activity on Mars are also provided by the mineralogical signature of its soils. According to recent studies (e.g., [66]), most of the mineral phases identified by CRISM (Compact Reconnaissance Imaging Spectrometer) images of NASA's Mars Reconnaissance Orbiter (MRO) satellite [65], could be of hydrothermal origin and are consistent with the deposition in an oxidizing environment. The associations of dominant haematite, hydrous potassium and iron sulfate jarosite and iron-oxides nanoparticles, besides several igneous minerals as olivine, pyroxene, magnetite evidenced by Mossbauer data (Figure 8A) detected in soils of Meridiani Planum by the Opportunity rover, represent constructive clues. In particular, jarosite typically forms by oxidation and hydrolysis of preexisting $\mathrm{FeSO}_{4}$ which does suggest the presence of hydrothermal $\mathrm{SO}_{3}$, indeed both goethite/haematite and jarosite are commonly found in the oxidized parts of hydrothermal mineral systems. Moreover, the high $\mathrm{SO}_{3}$ values detected for Martian soils by instruments (Alpha Particle X-ray Spectrometer) (e.g., [67]) of NASA's Spirit and Opportunity rovers (Figure $8 \mathrm{~B}$ ), further support the hypothesis of a past hydrothermal activity.
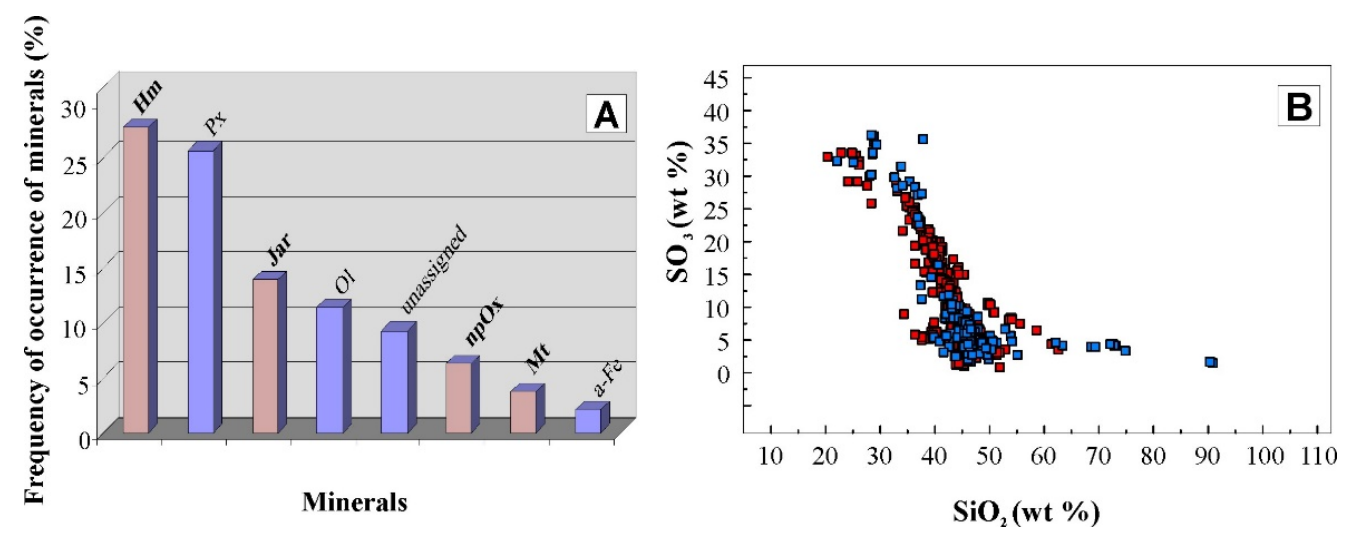

Figure 8. Mineralogical features and S abundance of the Martian analyzed soils. (A) Bar chart of the main analyzed iron minerals (Mossbauer data by Opportunity rover, MER Data Sets Online at Geosciences at link: https:/ / pds-geosciences.wustl.edu/missions/mer/geo_mer_datasets.htm accessed on 9 January 2019) $\mathrm{Hm}$ = hematite, $\mathrm{Px}=$ pyroxene, Jar = jarosite, $\mathrm{Ol}=$ olivine, $\mathrm{npOx}=$ iron oxide nanoparticles, $\mathrm{Mt}=$ magnetite, a-Fe = alpha iron. (B) $\mathrm{SiO}_{2}$ vs. $\mathrm{SO}_{3}$ variation diagram based on bulk chemical data (APXS) from the NASA database detected for Martian soils by NASA's Mars Exploration Spirit rover (blue squares) and Opportunity rover (red squares), (MER Data Sets Online at Geosciences at link: https://pds-geosciences.wustl.edu/missions/msl/apxs.htm accessed on 9 January 2019).

Also Michalski et al. [66] supported the hypothesis of a past hydrothermal activity on Mars. According to these authors, all the collected mineralogical data provide evidence of massive clay- and likely iron/sulphur-bearing oxide deposits, formed in a seawater hydrothermal environment on ancient Mars. They have been interpreted as seafloor deposits similar to those found on the Earth [66], and are a good analogue for the basin deposits remotely detected in the Eridania basin. Their formation required the presence of a primordial marine/volcanic basin involving hydrothermal activity in many areas along the Martian equator and, particularly, in sectors of the Eridania basin.

Other possible key areas affected by hydrothermal activity on Mars have been identified at Gusev Crater (landing site of the NASA's Mars Exploration rover Spirit in 2004) and Jezero Crater (landing site of the NASA's Perseverance rover in 2021) on the base of presence of amorphous opaline silica, a mineral phase with high potential to preserve biosignatures on Earth [68-70]. Specifically, in the Columbia Hills of Gusev Crater, the 
Mars Exploration rover Spirit, discovered in 2007 nodular clasts of opaline silica, adjacent to a volcanic tephra deposit called Home Plate $[69,71,72]$. The peculiar assemblages of minerals found by Spirit rover in this area suggested that opaline could have formed in hot springs or volcanic fumaroles from which silica precipitated [69,72]. Indeed, the profile of the Pioneer Mound (sol 1898) that lies near the edge of the Columbia Hills has been interpreted as extinct hot spring mounds since it resembles those occurred at Puchuldiza, in Chile $[69,72]$. Stratigraphic analysis of the Columbia Hills, in which hydrated silica was found in a discontinuous layer sandwiched between two volcanic units, support the occurrence of past hydrothermal activity $[69,72]$. Then, hydrated silica as well as Alphyllosilicate have been identified by Compact Reconnaissance Imaging Spectrometer for Mars (CRISM) in the Jezero Crater, which sits within the Isidis Planitia region [70]. The Jezero crater, represents the landing site for the ongoing ExoMars (ESA/Roscosmos) and Mars 2020 NASA's Perseverance rover mission [70] that aims to searching for potential biosignatures. At present, there is a wide variety of minerals exposed within Jezero, including many kinds of carbonates and clay minerals, which typically form in wet environments and are associated with volcanic minerals [73-78]. Since the 2020 Mars mission should return to Earth a suite of samples collected by the Perseverance rover via a Mars Sample Return mission [79], it will be of paramount interest to see if the hematite spherules are also present in the Jezero crater.

\section{Conclusions}

Future analyses and exploration missions will be essential to shed light on the specific mechanisms of formation of these haematite spherules and on their potential link with prebiotic or biotic conditions on Mars. Specifically, additional information on the mineralogical composition of the Martian spherules and sand and could highlight the presence of volcanic nuclei and potentially detect traces of residual/original goethite of hydrothermal origin. In this regard, the next and ongoing Mars missions (CNSA Tianwen-1, ESA/Roscosmos "ExoMars" and NASA "Mars 2020") should provide more information on morphology, mineralogy and composition of haematite spherules, such as those found at Meridiani Planum by NASA's Opportunity rover. Moreover, the Eridania region, the Meridiani Planum and the other areas where hydrothermal activity was hypothesized represent crucial areas for further surveys. In particular, the Eridania region considered as a fossil hydrothermal area [66], could potentially retain traces of biotic or prebiotic processes.

In conclusion, the impressive similarities-in terms of composition, shape, fabric and size - between Martian and terrestrial ooids of Panarea suggest a probable common hydrothermal-related genesis. The volcanic environment of Panarea, dominated by a young submarine shallow hydrothermal system, can be assumed to be a natural laboratory where the monitoring activity of its evolution in time may help to gain better insight into the geological dynamics and evolution occurred on the Red Planet as well. Moreover, since hydrothermal vents created favorable conditions to prebiotic processes and played a crucial role for the evolution of life on the Earth (e.g., [80]) our study could also open new perspectives on the everlasting search for life on Mars, as well as its fate.

Author Contributions: Conceptualization, M.D.B., F.I., S.Q., G.S. (Giuseppe Sabatino); methodology, M.D.B., G.S. (Giuseppe Sabatino), S.Q.; investigation, G.S. (Giuseppe Sabatino) and A.F.; writingoriginal draft preparation, M.D.B., F.I., S.Q., G.S. (Giuseppe Sabatino); writing-review and editing, F.P., R.D., R.B., B.C., A.F., F.A., T.R., V.E., A.T., G.S. (Gianfranco Scotti) supervision, M.D.B. All authors have read and agreed to the published version of the manuscript.

Funding: This research received no external funding.

Data Availability Statement: Data is contained within the article and can be provided by the authors. Mars data used in this work are publicly available by the Geosciences Node of NASA's Planetary Data System (PDS) archives. These data can be found here: https: / pds-geosciences.wustl.edu/ (accessed on 9 January 2019). 
Acknowledgments: The authors are deeply grateful to the anonymous reviewers for their insightful suggestions and comments which led to an improved manuscript. The authors also thank G. Confalonieri of the ESRF-ID22 beamline staff (Grenoble, France) for the synchrotron diffractometric experiments and data analysis. Offshore activities of this study were supported by the "European Multidisciplinary Seafloor and water-column Observatory European Research Infrastructure Consortium" project (EMSO ERIC) and the "Osservatorio della Biodiversità della Regione Siciliana" project (ORBS; DDG n. 101711 November 2013 of the Department of Territory and Environment of the Sicilian Region, Italy).

Conflicts of Interest: The authors declare no conflict of interest.

\section{References}

1. Christensen, P.R.; Morris, R.V.; Lane, M.D.; Bandfield, J.L.; Malin, M.C. Global mapping of Martian hematite mineral deposits: Remnants of water-driven processes on early Mars. J. Geophys. Res. 2001, 106, 873-885. [CrossRef]

2. Squyres, S.W.; Grotzinger, J.P.; Arvidson, R.E.; Bell, J.; Calvin, W.; Christensen, P.; Clark, B.C.; Crisp, J.A.; Farrand, W.H.; Herkenhoff, K.E.; et al. In situ evidence for an ancient aqueous environment at Meridiani Planum, Mars. Science 2004, 306, 1709-1714. [CrossRef]

3. Arvidson, R.E.; Squyres, S.W.; Anderson, R.C.; Bell, J.F.; Blaney, D.; Bruckner, J.; Cabrol, N.A.; Calvin, W.M.; Carr, M.H.; Christensen, R.R.; et al. Overview of the Spirit Mars Exploration Rover Mission to Gusev Crater: Landing site to Backstay Rock in the Columbia Hills. J. Geophys. Res. 2006, 111, E02S01. [CrossRef]

4. Klingelhofer, G.; Morris, R.V.; Bernhardt, B.; Schroder, C.; Rodionov, D.S.; de Souza, P.A., Jr.; Yen, A.; Gellert, R.; Evlanov, E.N.; Zubkov, B.; et al. Jarosite and hematite at Meridiani Planum from Opportunity's Mossbauer spectrometer. Science 2004, 306, 1740-1745. [CrossRef]

5. Morris, R.V.; Klingelhöfer, G.; Schröder, C.; Rodionov, D.S.; Yen, A.; Ming, D.W.; De Souza, P.A., Jr.; Fleischer, I.; Wdowiak, T.; Gellert, R.; et al. Mössbauer mineralogy of rock, soil, and dust at Gusev crater, Mars: Spirit's journey through weakly altered olivine basalt on the plains and pervasively altered basalt in the Columbia Hills. J. Geophys. Res. 2006, 111, E02S13. [CrossRef]

6. $\quad$ Rieder, R.; Gellert, R.; Anderson, R.C.; Bruckner, J.; Clark, B.C.; Dreibus, G.; Economou, T.; Klingelhoffer, G.; Lugmair, G.W.; Ming, D.; et al. Chemistry of rocks and soils at Meridiani Planum from the alpha particle X-ray spectrometer. Science 2004, 106, 1746-1749. [CrossRef] [PubMed]

7. Calvin, W.M.; Shoffner, J.D.; Johnson, J.R.; Knoll, A.H.; Pocock, J.M.; Squyres, S.W.; Weitz, C.M.; Arvidson, R.E.; Bell, J.F.; Christensen, P.R.; et al. Hematite spherules at Meridiani: Results from MI, mini-TES, and Pancam. J. Geophys. Res. 2008, 113, 1-27. [CrossRef]

8. Chan, M.A.; Beitler, B.; Parry, W.T.; Ormo, J.; Komatsu, G. A possible terrestrial analogue for haematite concretions on Mars. Nature 2004, 429, 731-734. [CrossRef]

9. Chan, M.A.; Potter, S.L.; Bowen, B.B.; Parry, W.T.; Barge, L.M.; Seiler, W.; Peters, E.U.; Bowman, J.R. Characteristics of terrestrial ferric oxide concretions and Implications for Mars. In Sedimentary Geology of Mars; Society for Sedimentary Geology Special Publication: Tulsa, OK, USA, 2012; Volume 102, pp. 253-270.

10. Yoshida, H.; Hasegawa, H.; Katsuta, N.; Maruyama, I.; Sirono, S.; Minami, M.; Asahara, Y.; Nishimoto, S.; Yamaguchi, Y.; Ichinnorov, N.; et al. Fe-oxide concretions formed by interacting carbonate and acidic waters on Earth and Mars. Sci. Adv. 2018, 4, eaau0872. [CrossRef]

11. Squyres, S.W.; Knoll, A.H.; Arvidson, R.E.; Clark, B.C.; Grotzinger, J.P.; Jolliff, B.L.; McLennan, S.M.; Tosca, N.; Bell, J.F.; Calvin, W.M.; et al. Two years at Meridiani Planum: Results from the Opportunity Rover. Science 2006, 313, 1403-1407. [CrossRef]

12. Grotzinger, J.P.; Arvidson, R.E.; Bell, J.F.; Calvin, W.; Clark, B.C.; Fike, D.A.; Golombek, M.; Greeley, R.; Haldemann, A.; Herkenhoff, K.E.; et al. Stratigraphy and sedimentology of a dry to wet aeolian depositional system, Burns Formation, Meridiani Planum, Mars. Earth Planet. Sci. Lett. 2005, 240, 11-72. [CrossRef]

13. McLennan, S.M.; Bell, J.; Calvin, W.M.; Christensen, P.; Clark, B.C.; De Souza, P.A.; Farmer, J.; Farrand, W.H.; Fike, D.A.; Gellert, R.; et al. Provenance and diagenesis of the evaporite-bearing Burns formation, Meridiani Planum, Mars. Earth Planet. Sci. Lett. 2005, 240, 95-121. [CrossRef]

14. Knauth, L.P.; Burt, D.M.; Wohletz, K.H. Impact origin of sediments at the Opportunity landing site on Mars. Nature 2005, 438, 1123-1128. [CrossRef]

15. Anupam, K.M.; Acosta-Maeda, T.E. Hematite Spherules on Mars; IntechOpen: London, UK, 2018. [CrossRef]

16. McCollom, T.M.; Hynek, B.M. A volcanic environment for bedrock diagenesis at Meridiani Planum on Mars. Nature 2005, 438, 1129-1131. [CrossRef] [PubMed]

17. Fan, C.; Xie, H.; Schulze-Makuch, D.; Ackley, S. A formation mechanism for hematite-rich spherules on Mars. Planet. Space Sci. 2010, 58, 401-410. [CrossRef]

18. Sexton, M.R.; Elwood Madden, M.E.; Swindle, A.L.; Hamilton, V.E.; Bickmore, B.R.; Elwood Madden, A.S. Considering the formation of hematite spherules on Mars by freezing aqueous hematite nanoparticle suspensions. Icarus 2017, 286, $202-211$. [CrossRef] 
19. Pirajno, F.; Hocking, R.M.; Reddy, S.M.; Jones, A.J. A review of the geology and geodynamic evolution of the Palaeoproterozoic Earaheedy Basin, Western Australia. Earth. Sci. Rev. 2009, 94, 39-77. [CrossRef]

20. Pirajno, F. Hydrothermal Processes and Mineral Systems; Springer: Berlin/Heidelberg, Germany, 2008.

21. Di Bella, M.; Sabatino, G.; Quartieri, S.; Ferretti, A.; Cavalazzi, B.; Barbieri, R.; Foucher, F.; Messori, F.; Italiano, F. Modern Iron ooids of hydrothermal origin as a proxy for Ancient Deposits. Sci. Rep. 2019, 9, 7107. [CrossRef]

22. Christensen, P.R.; Bandfield, J.L.; Hamilton, V.E.; Ruff, S.W.; Kieffer, H.H.; Titus, T.N.; Malin, M.C.; Morris, R.V.; Lane, M.D.; Clark, R.L.; et al. Mars Global Surveyor Thermal Emission Spectrometer experiment: Investigation description and surface science results. J. Geophys. Res. 2000, 106, 23823-23871. [CrossRef]

23. Weitz, C.M.; Anderson, R.C.; Bell, J.F.; Farrand, W.H.; Herkenhoff, K.E.; Johnson, J.R.; Jolliff, B.L.; Morris, R.V.; Squyres, S.W.; Sullivan, R.J. Soil grain analyses at Meridiani Planum, Mars. J. Geophys. Res. 2006, 111. [CrossRef]

24. Lane, M.D.; Morris, R.V.; Mertzman, S.A.; Christensen, P.R. Evidence for platy hematite grains in Sinus Meridiani, Mars. J. Geophys. Res. 2002, 107, 5126. [CrossRef]

25. Glotch, T.D.; Morris, R.V.; Christensen, P.R.; Sharp, T.G. Effect of precursor mineralogy on the thermal infrared emission spectra of hematite: Application to Martian hematite mineralization. J. Geophys. Res. Solid Earth 2004, 109. [CrossRef]

26. Glotch, T.D.; Christensen, P.R.; Sharp, T.G. Fresnel modelling of hematite crystal surfaces and application to Martian hematite spherules. Icarus 2006, 181, 408-418. [CrossRef]

27. Flahaut, J.; Carter, J.; Poulet, F.; Bibring, J.P.; Davies, G.R.; Murchie, S.L. Embedded clays and sulfates in Meridiani Planum, Mars. Icarus 2015, 248, 269-288. [CrossRef]

28. Arvidson, R.E.; Bell, J.F.; Catalano, J.G.; Clark, B.C.; Fox, V.K.; Gellert, R.; Grotzinger, J.P.E.; Guinness, A.; Herkenhoff, K.E.; Knoll, A.H.; et al. Mars Reconnaissance Orbiter and Opportunity observations of the Burns formation: Crater hopping at Meridiani Planum. J. Geophys. Res. Planets 2015, 120, 429-451. [CrossRef]

29. Squyres, S.W.; Arvidson, R.E.; Baumgartner, E.T.; Bell, J.F.; Christensen, P.R.; Gorevan, S.; Herkenhoff, K.E.; Klingelhofer, G.; Bo Madsen, M.; Morris, R.V.; et al. Athena Mars rover science investigation. J. Geophys. Res. 2003, 108, 8062. [CrossRef]

30. Klingelhoefer, G.; Morris, R.V.; Bernhardt, B.; Rodionov, D.; de Souza, P.A., Jr.; Squyres, S.W.; Foh, J.; Kankeleit, E.; Bonnes, U.; Gellert, R.; et al. Athena MIMOS II Mössbauer spectrometerinvestigation. J. Geophys. Res. 2003, 108, 8067. [CrossRef]

31. Squyres, S.W.; Arvidson, R.E.; Bollen, D.; Bell III, J.F.; Bruckner, J.; Cabrol, N.A.; Calvin, W.M.; Carr, M.H.; Christensen, P.R.; Clark, B.C.; et al. Overview of the Opportunity Mars Exploration Rover Mission to Meridiani Planum: Eagle Crater to Purgatory Ripple. J. Geophys. Res. 2006, 111. [CrossRef]

32. Pouchou, J.L.; Pichoir, L. Possibilités d'analyse en profondeur à la microsonde électronique. J. Microsc. Spectrosc. Electron 1984, 9 , 99-100.

33. Pouchou, J.L.; Pichoir, L. Les elements très legers en microanalyse X-Possibilités des modèles récents de quantification. J. Microsc. Spectrosc. Electron 1984, 11, 229-250.

34. Peccerillo, A. Plio-Quaternary Volcanism in Italy: Petrology, Geochemistry, Geodynamics; Springer: Berlin/Heidelberg, Germany, 2005; p. 365.

35. Lucchi, F.; Tranne, C.A.; Peccerillo, A.; Keller, J.; Rossi, P.L. Geological History of the Panarea Volcanic Group (Eastern Aeolian Archipelago); Geological Society: London, UK, 2013; Volume 37, pp. 351-395.

36. Lucchi, F.; Tranne, C.A.; Calanchi, N.; Rossi, P.L. Late quaternary deformation history of the volcanic edifice of Panarea, Aeolian Arc, Italy. Bull. Volcanol. 2007, 69, 239-257. [CrossRef]

37. Gamberi, F.; Savelli, C.; Marani, M.P.; Ligi, M.; Bortoluzzi, G.; Landuzzi, V.; Costa, M. Contesto morfo-tettonico e depositi idrotermali disolfuri ed ossidi di ferro in una porzione sommersa dell'arco eoliano (in base ad indagini ad alta definizione). Boll. Soc. Geol. Ital. 1997, 117, 55-71.

38. Marani, M.P.; Gamberi, F.; Casoni, L.; Carrara, G.; Landuzzi, V.; Musacchio, M.; Penitenti, D.; Rossi, L.; Trua, T. New rock and hydrothermal samples from the southern Tyrrhenian Sea: The MAR-98 research cruise. Gior. Geol. 1999, 61, 3-24.

39. Esposito, V.; Andaloro, F.; Canese, S.; Bortoluzzi, G.; Bo, M.; Di Bella, M.; Italiano, F.; Sabatino, G.; Battaglia, P.; Consoli, P.; et al. Exceptional discovery of a shallow-water hydrothermal site in the SW area of Basiluzzo islet (Aeolian Archipelago, South Tyrrhenian Sea): An environment to preserve. PLoS ONE 2018, 4, e0190710. [CrossRef]

40. Bortoluzzi, G.; Romeo, T.; La Cono, V.; La Spada, G.; Esposito, V.; Sabatino, G.; Di Bella, M.; Canese, S.; Scotti, G.; Bo, M.; et al. Ferrous iron- and ammonium-rich diffuse vents support diverse prokaryotic communities in a shallow hydrothermal field off the Basiluzzo Islet (Aeolian Volcanic Archipelago). Geobiology 2017, 15, 664-677. [CrossRef]

41. Italiano, F.; Nuccio, P.M. Geochemical investigations of submarine volcanic exhalations to the east of Panarea, Aeolian Islands, Italy. J. Volcanol. Geotherm. Res. 1991, 46, 125-141. [CrossRef]

42. Romano, D.; Gattuso, A.; Longo, M.; Caruso, C.; Lazzaro, G.; Corbo, A.; Italiano, F. Hazard Scenarios Related to Submarine Volcanic-Hydrothermal Activity and Advanced Monitoring Strategies: A Study Case from the Panarea Volcanic Group (Aeolian Islands, Italy). Geofluids 2019, 15, 8728720. [CrossRef]

43. Farrand, W.H.; Bell, J.F.; Johnson, J.R.; Jolliff, B.L.; Knoll, A.H.; McLennan, S.M.; Squyres, S.W.; Calvin, W.M.; Grotzinger, J.P.; Morris, R.V.; et al. Visible and near-infrared multispectral analysis of rocks at Meridiani Planum, Mars, by the Mars Exploration Rover Opportunity. J. Geophys. Res. 2007, 112. [CrossRef] 
44. Tosca, N.J.; Mclennan, S.M.; Clark, B.C.; Grotzinger, J.P.; Hurowitz, J.A.; Knoll, A.H.; SchrIder, C.; Squyres, S.W. Geochemical modeling of evaporation processes on Mars: Insight from thesedimentary record at Meridiani Planum. Earth Planet. Sci. Lett. 2005, 240, 125-151. [CrossRef]

45. Knoll, A.H.; Carr, M.; Clark, B.; Des Marais, D.J.; Farmer, J.D.; Fischer, W.W.; Grotzinger, J.P.; McLennan, S.M.; Malin, M.; Schroderi, C.; et al. An astrobiological perspective on Meridiani Planum. Earth Planet. Sci. Lett. 2005, 240, 179-189. [CrossRef]

46. Nimmo, F.; Tanaka, K. Early crustal evolution of mars. Annu. Rev. Earth Planet. Sci. 2005, 33, 133-161. [CrossRef]

47. Bouley, S.; Baratoux, D.; Matsuyama, I.; Forget, F.; Séjourné, A.; Turbet, M.; Costard, F. Late Tharsis formation and implications for early Mars. Nature 2016, 531, 344-347. [CrossRef]

48. Parker, T.J.; Gorsline, D.S.; Saunders, R.S.; Pieri, D.C.; Schneeberger, D.M. Coastal geomorphology of the Martian northern plains. J. Geophys. Res. Planets 1993, 98, 11061-11078. [CrossRef]

49. Fairen, A.G.; Dohm, J.M.; Baker, V.M.; De Pablo, M.A.; Ruiz, J.; Ferris, J.C.; Anderson, R.C. Episodic fluid inundations of the Northern Plains of Mars. Icarus 2003, 165, 53-67. [CrossRef]

50. Dohm, J.M.; Baker, V.R.; Boynton, W.V.; Fairen, A.G.; Ferris, J.C.; Finch, M.; Furfaro, R.; Hare, T.M.; Janes, D.M.; Kargel, J.; et al. GRS evidence and the possibility of paleooceans on Mars. Planet. Space Sci. 2009, 57, 664-684. [CrossRef]

51. Dohm, J.M.; Maruyama, S.; Kido, M.; Baker, V.R. A possible anorthositic continent of early Mars and the role of planetary size for the inception of Earth-like life. Geosci. Front. 2018, 9, 1085-1098. [CrossRef]

52. Michalski, J.R.; Bleacher, J.E. Supervolcanoes within an ancient volcanic province in Arabia Terra, Mars. Nature 2013, 502, 47-52. [CrossRef] [PubMed]

53. Hynek, B.M.; Arvidson, R.; Phillips, R.J. Geologic setting and origin of Terra Meridiani hematite deposit on Mars. J. Geophys. Res. 2002, 107. [CrossRef]

54. Christensen, P.R.; Ruff, S.W. Formation of the hematite-bearing unit in Meridiani Planum: Evidence for deposition in standing water. J. Geophys. Res. 2004, 109. [CrossRef]

55. Gualtieri, A.F.; Venturelli, P. In situ study of the goethite-hematite phase transformation by real time synchrotron powder diffraction. Am. Mineral. 1999, 84, 895-904. [CrossRef]

56. Wilson, J.T.; Eke, V.R.; Massey, R.J.; Elphic, R.C.; Feldman, W.C.; Maurice, S.; Teodoro, L.F.A. Equatorial locations of water on Mars: Improved resolution maps based on Mars Odyssey Neutron Spectrometer data. Icarus 2018, 299, 148-160. [CrossRef]

57. Pirajno, F.; Van Kranendonk, M.J. Review of hydrothermal processes and systems on Earth and implications for Martian analogues. Aust. J. Earth Sci. 2005, 52, 329-351. [CrossRef]

58. Dohm, J.M.; Ferris, J.C.; Baker, V.R.; Anderson, R.C.; Hare, T.M.; Strom, R.G.; Barlow, N.G.; Tanaka, K.L.; Klemaszewski, J.E.; Scott, D.H. Ancient drainage basin of the Tharsis region, Mars: Potential source for outflow channel systems and putative oceans or paleolakes. J. Geophys. Res. Planets 2001, 106, 32943-32958. [CrossRef]

59. Chojnacki, M.; Hynek, B.M. Geological context of water-altered minerals in Valles Marineris, Mars. J. Geophys. Res. 2008, 113, E12005. [CrossRef]

60. Weitz, C.M.; Milliken, R.E.; Grant, J.A.; McEwen, A.S.; Williams, R.M.E.; Bishop, J.L. Light-toned strata and inverted channels adjacent to Juventae and Ganges Chasmata, Mars. Geophys. Res. Lett. 2008, 35, L19202. [CrossRef]

61. Roach, L.H.; Mustard, J.F.; Murchie, S.L.; Bibring, J.P.; Forget, F.; Lewis, K.W.; Aharonson, O.; Vincendon, M.; Bishop, J.L. Testing evidence of recent hydration state change in sulfates on Mars. J. Geophys. Res. 2009, 114. [CrossRef]

62. Weitz, C.M.; Noe Dobrea, E.Z.; Lane, M.D.; Knudson, A. Geologic relationships between gray hematite, sulfates, and clays in Capri Chasma. J. Geophys. Res. 2012, 117, E00J09. [CrossRef]

63. Weitz, C.M.; Bishop, J.L. Stratigraphy and formation of clays, sulfates, and hydrated silica within a depression in Coprates Catena, Mars. J. Geophys. Res. Planets 2016, 121, 805-835. [CrossRef]

64. Bibring, J.P.; Soufflot, A.; Berthé, M.; Langevin, Y.; Gondet, B.; Drossart, P.; Bouyé, M.; Combes, M.; Puget, P.; Semery, A.; et al. OMEGA: Observatoire Pour La Minéralogie, l'Eau, Les Glaces et l'Activité. In ESA SP-1240: Mars Express: The Scientific Payload; ESA Publications Division: Noordwijk, The Netherlands, 2004; pp. 37-49.

65. Murchie, S.; Arvidson, R.; Bedini, P.; Beisser, K.; Bibring, J.P.; Bishop, J.; Boldt, J.; Cavender, P.; Choo, T.; Clancy, R.T.; et al. Compact Reconnaissance Imaging Spectrometer for Mars (CRISM) on Mars Reconnaissance Orbiter (MRO). J. Geophys. Res. 2007, 112. [CrossRef]

66. Michalski, J.R.; Noe Dobrea, E.Z.; Niles, P.B.; Cuadros, J. Ancient hydrothermal seafloor deposits in Eridania basin on Mars. Nat. Commun. 2017, 8, 15978. [CrossRef]

67. Rieder, R.; Gellert, R.; Brückner, J.; Klingelhöfer, G.; Dreibus, G.; Yen, A.; Squyres, S.W. The new Athena alpha particle X-ray spectrometer for the Mars Exploration Rovers. J. Geophys. Res. 2003, 108, 8066. [CrossRef]

68. Sánchez-García, L.; Carrizo, D.; Molina, A.; Muñoz-Iglesias, V.; Ángeles Lezcano, M.; Fernández-Sampedro, M.; Parro, V.; Prieto-Ballesteros, O. Fingerprinting molecular and isotopic biosignatures on different hydrothermal scenarios of Iceland, an acidic and sulfur-rich Mars analog. Sci. Rep. 2020, 10, 21196. [CrossRef] [PubMed]

69. Ruff, S.W.; Campbell, K.A.; Van Kranendonk, M.J.; Rice, M.S.; Farmer, J. The case for ancient hot springs in Gusev Crater. Mars. Astrobiology 2020, 4, 475-499. [CrossRef]

70. Tarnas, J.D.; Mustard, J.F.; Lin, H.; Goudge, T.A.; Amador, E.S.; Bramble, M.S.; Kremer, C.H.; Zhang, X.; Itoh, Y.; Parente, M. Orbital Identification of Hydrated Silica in Jezero Crater, Mars. Geophys. Res. Lett. 2019, 46, 12771-12782. [CrossRef] 
71. Squyres, S.W.; Arvidson, R.E.; Ruff, S.; Gellert, R.; Morris, R.V.; Ming, D.W.; Crumpler, L.; Farmer, J.D.; Des Marais, D.J.; Yen, A.; et al. Detection of silica-rich deposits on Mars. Sci. Rep. 2008, 320, 1063-1067. [CrossRef] [PubMed]

72. Ruff, S.W.; Farmer, J.D.; Calvin, W.M.; Herkenhoff, K.E.; Johnson, J.R.; Morris, R.V.; Rice, M.S.; Arvidson, R.E.; Bell, J.F.; Christensen, P.R.; et al. Characteristics, distribution, origin, and significance of opaline silica observed by the Spirit rover in Gusev crater, Mars. J. Geophys. Res. 2011, 116, E00F23. [CrossRef]

73. Ehlmann, B.L.; Mustard, J.F.; Murchie, S.L.; Poulet, F.; Bishop, J.L.; Brown, A.J.; Calvin, W.M.; Clark, R.N.; Des Marais, D.J.; Milliken, R.E.; et al. Orbital Identification of Carbonate-Bearing Rocks on Mars. Science 2008, 322, 1828-1832. [CrossRef]

74. Ehlmann, B.L.; Mustard, J.F.; Fassett, C.I.; Schon, S.C.; Head, J.W., III; Des Marais, D.J.; Grant, J.A.; Murchie, S.L. Clay minerals in delta deposits and organic preservation potential on Mars. Nat. Geosci. 2008, 1, 355-358. [CrossRef]

75. Goudge, T.A.; Mustard, J.F.; Head, J.W.; Fassett, C.I.; Wiseman, S.M. Assessing the mineralogy of the watershed and fan deposits of the Jezero crater. paleolake system, Mars. J. Geophys. Res. Planets 2015, 120, 775-808. [CrossRef]

76. Viviano, C.E.; Moersch, J.E.; McSween, H.Y. Implications for early hydrothermal environments on Mars through the spectral evidence for carbonation and chloritization reactions in the Nili Fossae region. J. Geophys. Res. Planets 2013, 118, $1858-1872$. [CrossRef]

77. Bramble, M.S.; Mustard, J.F.; Salvatore, M.R. The geological history of Northeast Syrtis Major, Mars. Icarus 2017, 293 , 66-93. [CrossRef]

78. Thomas, R.J.; Potter-McIntyre, S.L.; Hynek, B.M. Large-scale fluid-deposited mineralization in Margaritifer Terra, Mars. Geophys. Res. Lett. 2017, 44, 6579-6588. [CrossRef]

79. Williford, K.H.; Farley, K.A.; Stack, K.M.; Allwood, A.C.; Beaty, D.; Beegle, L.; Bhartia, R.; Brown, A.J.; de la Torre Juarez, M.; Hamran, S.E.; et al. The NASA Mars 2020 rover mission and the search for extraterrestrial life. In From Habitability to Life on Mars; Cabrol, N.A., Grin, E.A., Eds.; Elsevier: Amsterdam, The Netherlands, 2018; pp. 275-308.

80. Martin, W.; Baross, J.; Kelley, D.; Russell, M. Hydrothermal vents and the origin of life. Nat. Rev. Microbiol. $2008,6,805-814$. [CrossRef] [PubMed] 